\title{
Hot dog lymphadenopathy of prostate cancer
}

\author{
Simon Takada, ${ }^{1}$ Masahiro Nishimura, ${ }^{1}$ Kyouichi Yamaguchi, ${ }^{1}$ Yasuharu Tokuda ${ }^{2}$
}

${ }^{1}$ Shiritsu Nara Byoin, Nara, Japan

${ }^{2}$ Department of General Internal Medicine, Tsukuba University, Mito, Ibaraki, Japan

\section{Correspondence to}

Professor Yasuharu Tokuda, yasuharu.tokuda@gmail.com

Accepted 17 October 2016
CrossMark

\section{To cite: Takada $S$,} Nishimura M, Yamaguchi K, et al. BMJ Case Rep Published online: [please include Day Month Year] doi:10.1136/bcr-2016217160

\section{DESCRIPTION}

A man aged 77 years with diabetes and hypertension presented to our hospital with weight loss. The temperature was $36.7^{\circ}$, the blood pressure $117 / 68 \mathrm{~mm} \mathrm{Hg}$ and the pulse of $63 / \mathrm{min}$. Physical examination was normal. CT scan image with contrast enhancement of the abdomen revealed longitudinally fused bilateral massive para-aortic lymphadenopathy (figure 1A, B) with bilateral hydronephrosis. These images appeared to mimic a hot dog (figure 2A, B). Digital rectal examination identified the enlarged prostate. Prostate-specific antigen (PSA) was $517 \mathrm{ng} / \mathrm{mL}$ (normal range, 0-3.9 ng/mL). After he was admitted, a consultant urologist performed a prostate biopsy which showed the prostate cancer (figure 1C). A CT-guided needle biopsy of the para-aortic lymphadenopathy was also conducted and it
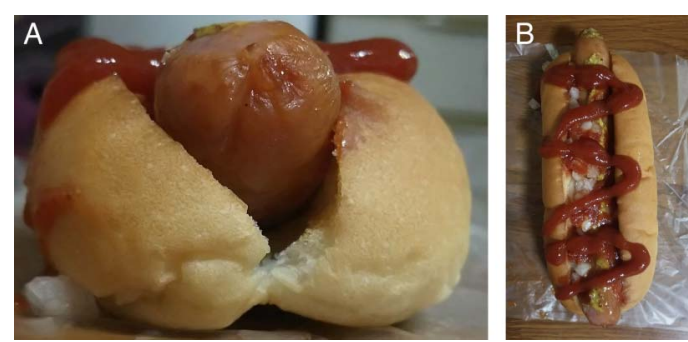

Figure 2 A hot dog ((A) axial view; (B) longitudinal view).

revealed the similar histological finding of prostate cancer (figure 1D). ${ }^{1}$ The patient underwent chemotherapy and hormone therapy and has been well at the time of the last follow-up at 3 months after the hospital discharge.
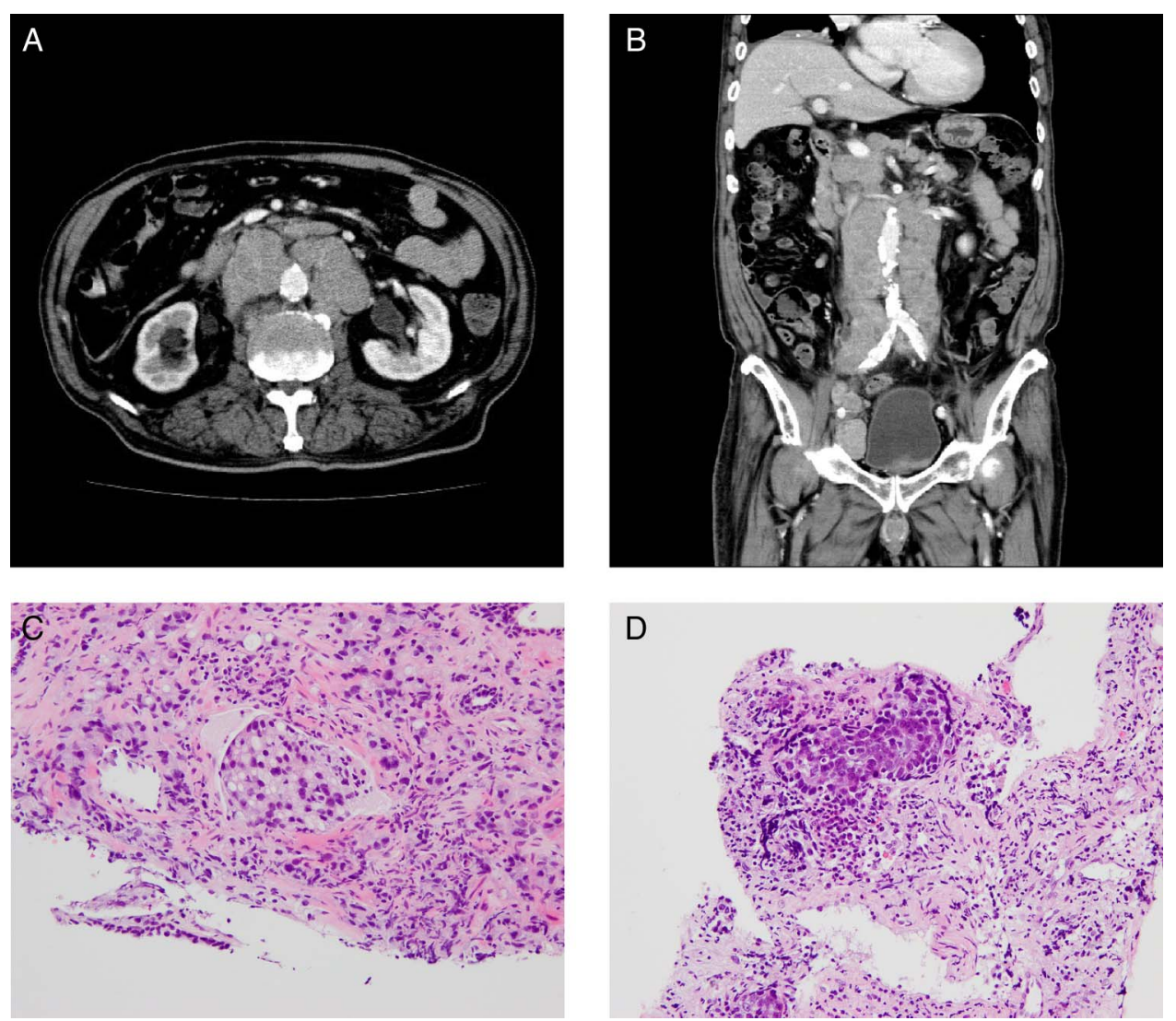

Figure 1 Longitudinally fused bilateral massive para-aortic lymphadenopathy ((A) axial view; (B) coronal view) and histological findings with H\&E stain ((C) prostate biopsy; (D) lymph node biopsy). 


\section{Learning points}

Prostate cancer may metastasise through lymphatics to para-aortic lymph nodes.

- Malignant swelling of para-aortic lymph nodes can mimic the shape of a hot dog.

- It is occasionally important to make a histological diagnosis of the para-aortic lymphadenopathy because of the potential curability.
Contributors ST, MN and KY cared for the patient. ST, MN, KY and YT wrote the manuscript.

Competing interests None declared.

Patient consent Obtained.

Provenance and peer review Not commissioned; externally peer reviewed.

\section{REFERENCE}

1 Haraoka M, Takamuki M, Toyonaga Y, et al. [Prostate cancer of unknown primary origin with multiple lymph nodes metastasis; a case report]. Nihon Hinyokika Gakkai Zasshi 2014;105:212-7.

Copyright 2016 BMJ Publishing Group. All rights reserved. For permission to reuse any of this content visit http://group.bmj.com/group/rights-licensing/permissions.

BMJ Case Report Fellows may re-use this article for personal use and teaching without any further permission.

Become a Fellow of BMJ Case Reports today and you can:

- Submit as many cases as you like

- Enjoy fast sympathetic peer review and rapid publication of accepted articles

- Access all the published articles

- Re-use any of the published material for personal use and teaching without further permission

For information on Institutional Fellowships contact consortiasales@bmjgroup.com

Visit casereports.bmj.com for more articles like this and to become a Fellow 